stature, of the differences between the two foregoing (which indicate the total length of the lower limbs), and of the span. Anthropologists seem to have little idea of the wide fields of inquiry open to them as soon as they are prepared to deal with individual variety and cease to narrow their view to the consideration of the average.

Enough has now been said to justify the claims with which I started, and which take this final form. First, wherever it is likely to be of use, that, in series of which the $M$ is calculated, the measures at a certain number of selected grades should also be calculated and given, sufficient to enable the rest of the series to be found with adequate accuracy by interpolation. Secondly, that the value of $Q$ should always be given, as well as that for $M$, for two reasons. The one is, that they suffice between them to give an approximate determination of the whole series, more closely approximate as the series is more closely of the normal type ; and, secondly, because $Q$ is an essential datum before any application can be made of the law of frequency of error. The properties of this law are, as we have seen, largely available in anthropological inquiry. They enable us to define the trustworthiness of our results, and to deal with such interesting problems as those of correlation and family resemblance, which cannot be solved without its help.

Table of ordinates to normal iurve of distribution, in which the unit = the probable error, and the grades, which are the abscisse, run from $0^{\circ}$ to $100^{\circ}$.

\begin{tabular}{|c|c|c|c|c|c|c|c|c|c|c|}
\hline Grades. & o & I & 2 & 3 & 4 & 5 & 6 & 7 & 8 & 9 \\
\hline 0 & $\infty$ & -345 & -305 & -279 & -2.60 & -2.44 & $-2^{1} 3^{I}$ & $-2 \times 9$ & $-2 \cdot 08$ & $-\mathrm{I}$ \\
\hline 10 & $-r .90$ & -1.82 & $-\mathrm{I} \cdot 74$ & $-x^{6} 67$ & $-1.6 c$ & $-\mathrm{I} 54$ & $-I^{4} 47$ & $-\mathrm{I}^{\prime} 42$ & $-\mathbf{I}^{*} 3 \mathrm{E}$ & \\
\hline 20 & $-x \cdot 25$ & -120 & $-I_{15}$ & -1.10 & -1.05 & -100 & -0.95 & $|-0.9 \mathrm{I}|$ & -0.86 & \\
\hline 30 & -0.78 & $-0^{\prime} 74$ & $-0^{\circ} 69$ & -0.65 & -0.61 & -0.57 & $-0^{\circ} 53$ & -0.49 & $-0^{\circ} 45$ & \\
\hline 40 & -0.38 & $-0^{\circ} 34$ & $\mid-0^{\circ} 30$ & -0.26 & -0.22 & - o.10 & $-0 \times 5$ & -0.12 & -0.07 & -0 \\
\hline 50 & 0.00 & $+0^{\circ} \mathrm{O}_{4}$ & $+0^{\circ} 07$ & to 11 & $+0 \times 5$ & to.19 & $+0^{\circ} 22$ & +0.26 & to 30 & \\
\hline 60 & $+0.3^{8}$ & $+0_{4} 4 \mathrm{r}$ & +0.45 & +0.49 & $+0^{\circ} 53 \mid$ & +0.57 & +0.61 & +0.65 & +0.69 & \\
\hline 70 & +0.78 & $\mid+0.82$ & +0.86 & +0.91 & +0.95 & +100 & $+r^{\circ} 05$ & +r.ro & $+\mathrm{I}^{\prime} 15$ & \\
\hline 80 & +1.25 & $+I^{\prime} 30$ & $+\mathrm{I} \cdot 36$ & +142 & & $\mid+I .54$ & $+x^{2} 60$ & $+x^{\prime} 67$ & +r'74 & $+I$ \\
\hline 90 & +199 & & & +2.19 & +231 & $+22^{\circ}$ & +260 & $+2^{\prime} 79$ & +305 & +3 \\
\hline
\end{tabular}

This table is an inverse rendering of the values derived by interpolation from the ordinary table of the probability integral, but its unit is changed from that of the modulus to that of the probable error, $Q$, and the (centesimal) grades are reckoned from $o^{\prime}$ to roo $^{\prime \prime}$. In the usual way of reckning, the 5oth on the one side down to $-50^{\circ}$, and on the other up to $+50^{\circ}$.

Referring to what was said some way back, that if 30 per cent. fail to ful 60 pounds, then $\epsilon_{0}$ pounds must be taken as the measure corresponding to grade $30^{\circ}$, the reason is as follows. The zoth grade separates the man who ranks 3 oth in a class of 100 men from his neighb ur who ranks 3 Ist. It does so for the same reason that grade $I^{2}$ separates the man who ranks Ist from the man who ranks and. Now, the soth man failed in the test, and the $3^{\text {rst }}$ succeeded. Therefore the grade corresponding to bare success lies between them, and is the same as grade $30^{\circ}$.

\section{SUPPOSED FOSSILS FROM THE SOUTHERN} HIGHLANDS.

$\mathrm{O}^{\mathrm{N}}$ Monday, the r4th instant, the Royal Society of Edinburgh held a special meeting for the purpose of hearing a discussion on the crystalline rocks of the Scottish Highlands. The subject was brought forward by the Duke of Argyll, who had found in the quartzite beds which cross Loch Fyne near Inveraray certain markings which he believed to be of organic origin. His attention was first called to some ferruginous stalklike incrustations on the surfaces of fragments of quartzite, his impression being that these markings were the remains of plants, and were embedded in the rock. The importance of the discovery of organic remains in any of the rocks that form the Central and Southern Highlands of Scotland will at once be recognized by geologists. Since the recent work of the Geological Survey in Sutherland and Ross, and the demonstration thereby afforded that the apparent upward succession on which Murchison relied, from the base of the lowest quartzite up into the upper or eastern or younger gneisses, is deceptive, there has been, perhaps, a tendency to assume that the extraordinarily complicated structure that supervenes to the east of the quartzites and limestones of Sutherland extends across the whole of the rest of the Highlands, and that the crystalline schists of these regions are made up of all kinds of crushed and sheared igneous or sedimentary masses, out of which it may be impossible to make anything like intelligible order. But those observers who have themselves examined the schists of the central and southern counties of the Highlands are tolerably confident that such assumptions have no warrant in the actual structure of the ground. On the contrary, they regard the greater proportion of the schistose and altered rocks of these districts as unquestionably of sedimentary origin. They feel persuaded that sooner or later they will be found to yield fossils, and that any day may bring to light a series of corals, shells, graptolites, or trilobites, which will furnish a palæontological basis for settling the geological age of the rocks, and placing them in their true position with regard to the Palæozoic formations of the rest of the country.

The announcement that the Duke of Argyll had found what seemed to be organic remains in the Inveraray quartzites awakened accordingly much interest among geologists. His Grace soon discovered, however, that what he had at first believed to be fossils were only external markings due to the precipitation of hydrous peroxide of iron round the decaying stems of mosses, heaths, or other plants. These markings occurred indifferently on pieces of quartzite, mica-schist, gneiss, \&c., and in no instance were found within the stone, but always on the surface. But in turning over the exposed blocks of quartzite the Duke found numerous ferruginous markings which undoubtedly occurred all through the interior of the rock. After quarrying away portions of the solid rock, collecting a large series of specimens, and comparing them with others obtained from the quartzite of Sutherland, he deemed himself in a position to announce the probably organic nature of these markings; and the paper which he communicated last week to the Royal Society of Edinburgh gave the results of his inquiries. The bodies which he regards as fossils are compared by him to the "annelid burrows" which form so prominent a feature in the quartzites of Sutherland and Ross. He recognizes in the Inveraray rock similar ovate sections, the position and form of each tube being marked by a ferruginous ring, which is well defined along its inner margin, but fades outward into a general discoloration of the stone. He points out that in the Inveraray rock, as in that of the North-West Highlands, there is a general tendency of these ovate bodies to lie in one prevalent direction; and though he admits that the rocks have been considerably disturbed and crushed, he cannot trace among them any evidence of such stupendous movements as have been described from Sutherland. Accordingly he is disposed to look upon the parallelism of the stripes into which he thinks the original tubes have been flattened as evidence of the direction in which the worms burrowed through the still soft sand.

Perhaps the most original and valuable part of the Duke's paper was the account which he gave of his own experiments on the habits of the common lob-worms of our present shores. He had watched the operations of these creatures on the beach of dark silt at Inveraray; had cut out portions of the silt with the burrows and mounds intact, and had these removed to his own drawing-room to enable him to watch them more attentively. He had likewise injected plaster of Paris into the vertical or winding passages made by the worms in the silt, and had thereby obtained casts of the interior of these tunnels. He exhibited a very interesting and valuable collection of specimens illustrating these researches.

Mr. Geikie, the Director-General of the Geological 
Survey, opened the discussion, and regretted that, though he had enjoyed the advantage of seeing the large collection of specimens made by the Duke of Argyll from the Inveraray quartzite, ard also of examining the rock in situ, he was still unconvinced that the markings were really of organic origin. It was possible, he thought, to trace a series of stages from single crystals or irregular groups of crystals of pyrites through variously shaped aggregates into the "ovate bodies" of the Duke. In the more solid, massive, and uncrushed portions of the quartzite, these aggregates could be seen quite fresh, and probably not far from their original shape. But wherever the rock had undergone shearing (and this was the case throughout most of its mass), its component particles had been drawn out in the direction of movement, the original irregular, rounded or egg-shaped aggregates of sulphide of iron had been flattened and elongated, becoming eventually mere strips that run parallel to each other. The trend of these strips exactly coincided with that of the long axes of the foliation-minerals in the surrounding rocks, and were regarded by Mr. Geikie as pointing to the results of shearing in the rock-mass and not to the burrowings of worms. The ferruginous rings seemed to him to be due to an oxidation and leaching out of the pyritous matter of the little mineral aggregates, as so often happens among the Carboniferous and Jurassic sandstones that contain ferruginous concretions. While he could not admit that the markings in the quartzite of Inveraray had yet been shown to be of organic origin, he thought it quite possible that the precipitation of the iron-disulphide had originally taken place in presence of decomposing organic matter, as in many blue muds of the present day, and that portions of such pyritous mud had been drifted into the sandy deposit which is now quartzite.

Mr. B. N. Peach, of the Geological Survey, was also unable to recognize organic forms among the Inveraray markings. He thought that the parallelism of these markings where they were most elongated, and their coincidence with the general line of shearing movement in the rock, cast doubt upon their having any connection with worm-burrows.

Mr. Murray, of the Challenger Expedition, who thinks that sandstone deposits generally are sub-aërial formations, was disposed to refer the so-called annelid tubes of the Sutherland quartzite not to the borings of marine worms, but to the remains of terrestrial plants that grew upon sand-dunes.

In a paper which followed this discussion, Mr. Geikie gave an account of the evidence supplied by the rocks of the Highlands of remarkable deformation by mechanical movements. Illustrating his remarks by a large series of specimens, he showed how the Cambrian conglomerate of Assynt had its pebbles of quartz drawn out and its original sandy mud converted into a fine micaceous schist; how the conglomerates of the Central Highlands had their quartz-pebbles flattened like buttons and drawn out in the direction of movement, while their envelope of original sand and mud had been changed into a quartzschist ; how the granular quartzite of Sutherland had been crushed and rolled out into a thoroughly schistose mass ; how the coarse Archæan pegmatites had been likewise crushed down until their material had, as it were, flowed onwards so as now to show a close parallel to the "fluxionstructure " of many porphyries, and even to assume a finely laminated or shaly structure,'and lastly, how the highly crystalline basic dykes of the most ancient gneiss of the northwest had been sheared and rearranged until they passed into the most perfect forms of sericite-schist. He adverted to the obviously sedimentary origin of the great mass of the rocks constituting the Highlands east of the line of the Great Glen, and mentioned that the recent work of the Geological Survey in tracing the great belt of limestones from the coast of Banffshire through the Grampians into Argyllshire afforded now a good horizon, from which it might be hoped the general structure of the Highlands might be worked out. He exhibited specimens of quartzite from Perthshire and other districts containing various markings, some of which there could be little doubt were of organic origin. He also showed a singularly interesting series of specimens which he had recently received from Dr. Reusch, of the Geological Survey of Norway, displaying recognizable trilobites and corals embedded in a finely crumpled micaceous schist, exactly similar in character to much of the schist that constitutes wide regions in the Scottish Highlands. These specimens afforded much encouragement to search for fossils in the calcareouswand ferruginous layers and concretions that occur so frequently among our finer mica-schists and phyllites.

\section{THE LAW OF STORMS IN CHINA.}

THE law of storms in Hong Kong was investigated by aid of the lithographed paths of the typhoons in I 884 and 1885 , published in "Observations and Researches made in 1886 " and in those of 1885 and 1887 now in course of publication. Only those within 300 miles of the Observatory were considered in this connection. The angles between the wind and the radius vector, i.e. the line joining the Observatory with the centre of the typhoon, were measured and mean values derived, and the same was done for Victoria Peak (I 8 I 6 feet above the sea) and for the lower clouds.

No connection could in any case be traced between the distance from the centre and the direction of the wind, but the latter depends upon the bearing of the centre. As pointed out in "The Law of Storms in the Eastern Seas" (NATURE, vol. xxxv. p. I36), and elsewhere, the wind has a tendency to blow along the southern coast of China when a typhoon is raging in the China Sea, so that the wind in such cases veers only about half as much while the typhoon moves westward as in other cases, and this is the reason why the angle between the wind and the radius vector is larger than usual when the centre is situated to the south of Hong Kong.

When there is a typhoon anywhere between north and east within 300 miles of the colony-which, however, is not common - the wind at the Peak (about north-northwest) blows away from the centre - much more so than the clouds, which in fact describe almost a circle round the centre in that case; and this remarkable feature or something very like it has been found to obtain also at Ben Nevis with the centre of a depression in the north-e.st.

The angle between the wind and the radius vector is, at the Observatory, $8 i^{\circ}$ north of the centre, $55^{\circ}$ to the west, $56^{\circ}$ to the south, and $58^{\circ}$ to the east. At the Peak, it is $91^{\circ}$ to the north, $87^{\circ}$ to the west, $81^{\circ}$ to the south, and $78^{\circ}$ to the east. At the level of the lower clouds, it is $92^{\circ}$ to the north, $85^{\circ}$ to the west, $67^{\circ}$ to the south, and $86^{\circ}$ to the east.

The observations made at South Cape (Formosa) were treated similarly, with the following result: to the north of the centre the angle was $50^{\circ}$, to the west $50^{\circ}$, to the south $64^{\circ}$, and to the east $47^{\circ}$.

The angle observed on board ship in the China Sea in typhoons-say in about $16^{\circ}$ N. lat.--is on an average $47^{\circ}$, as previously published; at South Cape $\left(22^{\circ} \mathrm{N}\right.$. lat., the same as Hong Kong) $54^{\circ}$; at Hong Kong $62^{\circ}$; at Victoria Peak, above Hong Kong, $84^{\circ}$; and at the level of the lower clouds $82^{\circ}$. The angle previously obtained from observations made on board ship, and also at coast stations in about $32^{\circ} \mathrm{N}$. lat., was $75^{\circ}$ on an average, but so far north it seems to be more variable than in the China Sea, where it has been found remarkably constant, between (say) $12^{\circ} \mathrm{N}$. and $20^{\circ} \mathrm{N}$. But from the figures given it is seen that the angle increases with the latitude and with elevation above sea-level. The woodcut represents a typhoon in the neighbourhood of Hong Kong, or rather 